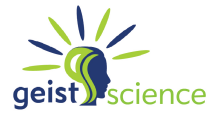

\title{
The Impact of Sectoral Foreign Direct Investment on
}

\section{Industrial Economic Growth of Pakistan}

\author{
M. Tahir Suleman * Muhammad Talha Amin ${ }^{\dagger}$
}

\begin{abstract}
This study examines the impact of sectoral foreign direct investment on industrial economic growth of Pakistan, by means of Cobb-Douglas production function. Three sectors were used namely manufacturing, construction, mining 83 quarrying for panel data during the period of 1997 to 2011. This study used three standard panel unit root tests; PP statistics panel unit root, ADF statistic, IPS panel unit root test. Moreover, to test the co integration between the variables, three different types of test were used for the panel co integration test based on Johansen fisher, Kao residual cointegration, Pedroni residual cointegration tests to find the long run relationship between sectoral FDI and industrial economic growth of Pakistan and the. Results revealed that sectoral FDI has positively and significantly affect the industrial growth of Pakistan.
\end{abstract}

Keywords: Pakistan; Cobb-Douglas, panel unit root test, panel cointergration test; long-run relationship

\section{Introduction}

Extant literature proved that foreign direct investment (FDI) plays a positive role in the process of economic growth. Developing countries like Pakistan have a challenge to fill the gap between saving and investment. In such scenario FDI can play vital role in economic growth and filling saving-investment gap by increasing productivity, transferring advanced technology, employment creation and enhancing competition (Kobrin, 2005) These benefits have motivated developing countries to liberalize their FDI policies and attract foreign investors for FDI inflows in their countries. In the early 1990s, the government of Pakistan took regulatory steps and amended its policies to improve the business environment and attract foreign investment.

During past two decades Pakistan has received comparatively higher amount of FDI, due to its market-oriented investment policies and enabling investment environment.

FDI inflows to Pakistan as percentage of gross domestic product (GDP) has been insignificant until 1991 due to inconsistent investment policies; however, it increased steadily in the post-liberalization period. Actual inflows of FDI to Pakistan in 1975-79 $\$ 119.6$ million which increase to $\$ 3299.8$ million in $1995-99$ and in $2001-02$ from $\$ 485$ million to $\$ 5,152.80$ million in $2007-08$ and in $2010-14$ from $\$ 3184$ million to $\$ 2677$ million (Foreign Direct Investment Flows, 2015) has showed a declining trend since

\footnotetext{
*School of Business and Information Technology, Wellington Institute of Technology, E-mail: tahir.suleman@weltec.ac.nz

$\dagger^{\dagger}$ Business Graduate, IQRA University Karachi, Pakistan.
} 
2007-08, which is due to the lack of enabling environment for investment in the country in recent years.

It is believed that any country's industrial sectors holds a significant importance in its economy. Without a strong industrial sector a country cannot compete economically in the modern world. In Pakistan the industrial production growth rate during the year 2012-13 was 20.9\%. Large Scale Manufacturing has also witnessed an improvement. It has shown a growth of 2.8 percent up to July-February 2012-13 against the 1.2 percent growth of same period previous year. But the growth was 4.26 percent in July-March 2012-13 as against 1.49 percent previous year (Highlights Pakistan Economic Survey 2012-13, 2015, January).

Most of the present economic problems in Pakistan are ultimately linked to the slow pace of industrial development. Rapid industrialization is considered by the economic exports as the sovereign remedy to provide a strong base for our economy. Importance of Industrial sector in Pakistan and role of industrial sector in economic development is crucial. Similarly manufacturing and construction sector has its own importance because of its benefits like globalization and particularly exports which results generate higher foreign exchange reserve and ameliorate employment rate in the country.

Manufacturing sector is the third largest sector of Pakistan economy. It comprised of large, medium and small-scale industries, and Pakistan invests heavily in its semimanufacturing and textile industry. Manufacturing sector contributes approximately $15 \%$ to GDP ${ }^{1}$. The mining \& quarrying industry in Pakistan have high potential and it could become the main and the most contributing sector of industry contributing 14.74 percent in overall industrial sector. Construction sectors stands next in the order of significance in Pakistan's industrial sector contribution $11.42 \%$ in the overall industrial sector.

Figure 1: Manufacturing sector output and FDI graph

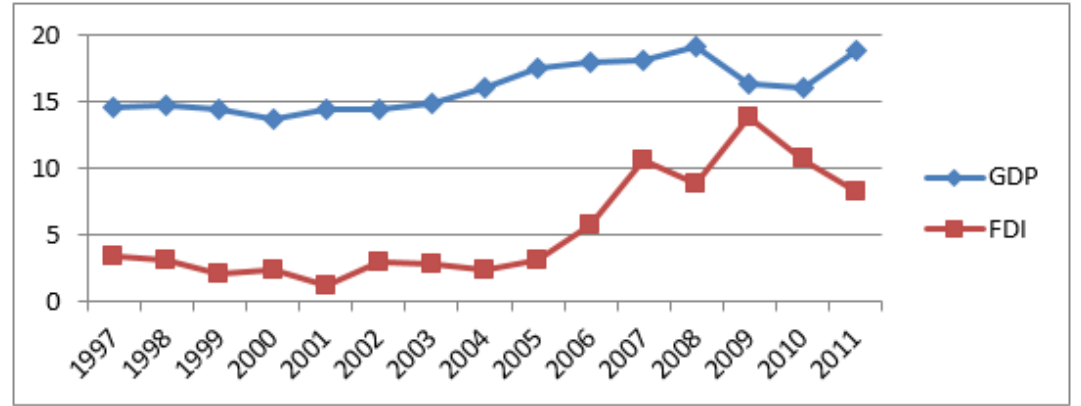

Author's: Estimation

The above graph shows that there was a continuous increase in output of the sector from 1997-2008 then there was a modest decline in the output, similarly FDI faced fluctuation from 1997-2005, after that there was a uplift but if we compare FDI and GDP graph we don't see the same uplift on output of the manufacturing sector as it was in FDI from period 2006-2008.

\footnotetext{
${ }^{1}$ (Economic \& Survey, 2012-2013)
} 
Figure 2: Construction sector output and FDI graph

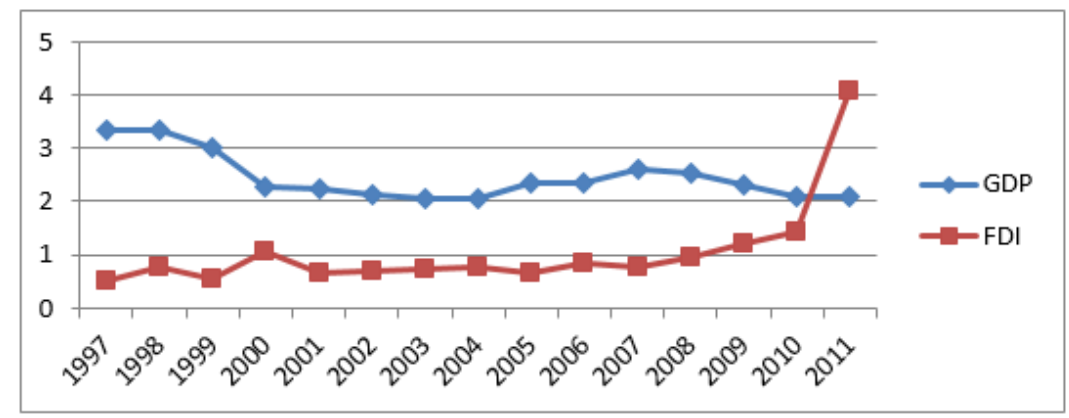

Author's: Estimation

The above graph shows that there was a continuous decline in output of the sector from 1997- 2011 then there was a modest uplift of the output, similarly FDI faced fluctuation from 1997-2007 after that there was a uplift but if we compare the FDI \& GDP graph, it is observed that FDI increased from 2007-2010 but output was still going downwards.

\section{Figure 3: Mining \& Quarrying sector output and FDI graph}

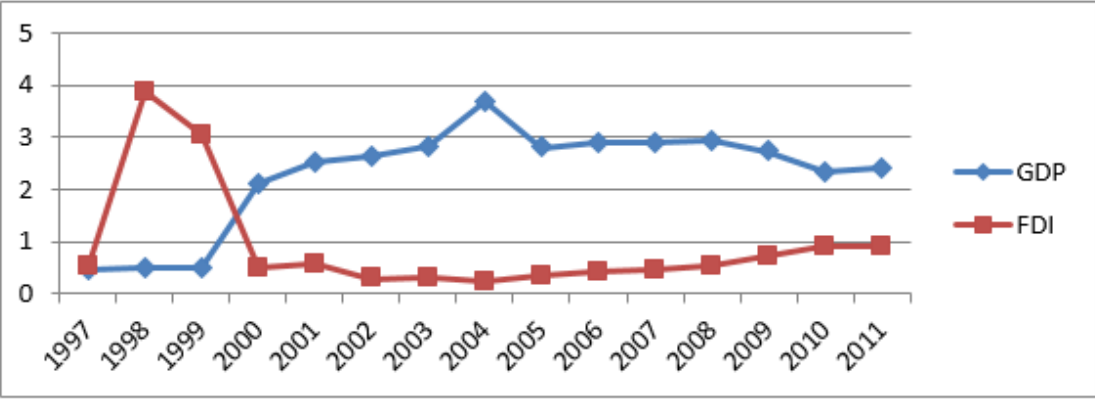

Author's: Estimation

The above graph shows that there was a continuous increase in output of the sector from 1999-2008, but from 2003-2005 there was a boom in the output then there was a modest decline in the output, similarly FDI faced uplift from 1997-2000 after that there was a continuous decline till 2007.

\section{Motivation of the Study}

Many Studies have been conducted in the past over the panel data both at aggregate and disaggregate level to find out the FDI and economic growth nexus and found that FDI has a positive and significant relationship with economic growth (Adeleke, 2014; Uttama, 2011), whereas other found that FDI negatively affects economic growth 
(Khaliq, Noy, et al., 2007; Alfaro, 2003). In case of Pakistan a study (Iram \& Nishat, 2009) examined the sectoral data analysis and its effect on economic growth by using aggregate level FDI. Our research focuses on FDI-growth nexus regarding to manufacturing sector, construction sector, and mining \& quarrying sector. We have done our research on disaggregate level FDI by which we will be able to measure the contribution of FDI on its particular. Looking at the above studies a conclusion is drawn that, there is still a need to expand the study with new data set regarding the sectoral data analysis.

The intention of this research is to observe the effect of sectoral FDI namely construction, manufacturing, and mining \& quarrying on industrial economic growth of Pakistan. Similarly we also faced issues regarding FDI, the unavailability of FDI data sector wise in yearly as well as monthly records earlier than 1997 and following 2012. This restricted our focus to data from 1997-2011. Pakistan had a significant impact on the South Asian industrial growth, our research will help the government of Pakistan to map a route for the economy in future times, it will also help the government to identify the sectors which should be given additional and proper attention and support for their growth.

The rest of the paper is organized as follows, chapter two includes theoretical background and literature review, chapter three describes the methodology, chapter four explains the results and final section contains conclusion and recommendations.

\section{Theoretical Underpinning}

There are numerous studies on the association between FDI and economic development on developed countries as well as developing countries, some of the research shows negative relationship while others show positive relationship. Studies that focus on data from developed countries generally show negative relationship, or no benefits for the host country, while data from developing country tends to have positive links.

In most studies empirical work is based on Solow's neo-classical model; neo-classical model defines relationship by explaining following channels.

1. MNF in host country role.

2. Determinates of FDI.

3. Causality and its direction between two variables.(Chowdhury \& Mavrotas, 2005)

It states that factor accumulation and total factor productivity are the two main sources of economic growth.(Felipe, 1999) Opposite to the neoclassical is the new growth theory which postulate that FDI can only contribute to economic development through development of technological knowledge and its transmission and capital formation (Borensztein, De Gregorio, \& Lee, 1998; Blomström \& Kokko, 1996) and the expansion of labor skills and training. In its framework several channels are at work, first FDI diminishes the entry barriers of the host country industries, secondly it amplifies the level of skills and knowledge of host country through labor and management, Third FDI increases capital accumulation by new technologies and new inputs.(Dunning, 1993; Blomström \& Kokko, 1996; Borensztein et al., 1998)

The similarity between neo classical and new growth theory is that one key factor in both is capital accumulation, but it is the technological faction which makes them different from each other. We can also states that neo classical model shows the direct 
contact of FDI on economic growth while the New Growth theory shows the indirect impact or spillovers of FDI, the spillover could be positive or negative.

Kindleberger (1984); Caves $(1974,1971)$ extended the industrial organization theory of FDI to emphasize the behavior of MNFs. According to them when MNF'S goes international then they have to face alien territory disadvantages so MNF'S carry on their production if they have some advantage over domestic competitors. A model was established by (Koizumi \& Kopecky, 1977) which focused and explained the gain of technology to subsidiary from its parent company and was assumed to be a positive function of the level of foreign capital stock in the host country.

The scholars of dependency theories viewed FDI from developed countries as a damaging factor in the long-run for developing countries, early studies (Singer, 1950) stated that multinational firms (MNF) captured all the benefits and returned it to their home countries and FDI receiving countries received very minor benefits (Boss et al., 2009). Other factors are also defined which created negative impact of FDI on economic growth, such as depletion of natural resources, and the monopoly of certain MNF'S price distortions. They further argued that MNF'S are imperialist predators and responsible for natural resources depletion in developing countries (World Investment Report, 1999). Hein (1992) responded to this argument by showing that Latin America restriction to FDI resulted in poor economic growth on the contrary South Asian countries encouraged FDIs which induced rapid economic growth. Later Firebaugh (1992) found that least developed countries (LDCs) tend to exhibit faster rates of both long run and short-run economic growth if they get greater rates of foreign investment. The contradicting results shift attention from the negative effects of FDI to the potentials of FDI and its positive effects.

\section{Empirical Studies}

Blomstrom, Lipsey, and Zejan (1992) examined the relationship between economic development and FDI. Results recommended that the FDI has affirmative impact on gross domestic product (GDP) for developing countries with higher income, but not for countries with lower income. Borensztein et al. (1998) scrutinized the effect of FDI on economic development in a cross-country investment, $\mathrm{H}$ the stock of human capital, Y initial GDP per capita and dependent is gross domestic product (GDP). Result suggest that FDI has the positive impact on gross domestic product (GDP).

Aitken and Harrison (1999) examined FDI to promote technology "spillovers" from domestic firms to foreign firms by using panel data Housman test. It was discovered that FDI have negatively affected the output of domestic plants. Addison and Heshmati (2003) examines the determinants of FDI inflows to developing countries by using Granger causality test from (1980-2000). The result shows that economic growth, openness to trade and flow of FDI has an affirmative association, whereas FDI and level of risk affects has a negative. Bengoa and Sanchez-Robles (2003) examined the interplay among economic development, FDI and economic freedom. In this research the panel data analysis was used from the data of 18 Latin American countries from 1970-1999. Our outcomes advocate that FDI is positively interrelated with economic development in the host countries we also find that economic freedom in the host country is a positive determinant of FDI inflows.

Alfaro (2003) explored the effect of FDI on services sectors, primary development and manufacturing. An experimental scrutiny was applied using cross-country data for the period 1981-1999. Results showed that total FDI have an uncertain effect 
on economic development. FDIs in the primary sector, however, is liable to have a pessimistic and insignificant effect on economic development, while investment in manufacturing has an affirmative effect on economic development. Katerina, John, and Athanasios (2004) examined the impact of FDI on economic progress focused on the western European countries and American countries and found that the nature of the effect of FDI for the panel of transition economies by using Bayesian analysis results indicated that FDI does not have any noteworthy relationship with economic development for the transition countries.

Atique, Ahmad, and Azhar (2004) examined the effect of FDI on economic development. The test which was used to discover the impact of FDI on economic development was Augmented Dickey Fuller (ADF), result recommended that FDI has an affirmative impact on economic development. Yao (2006) inspected the effect of FDI and exports on economic development, using the data of a set encircling 28 provinces of China a large panel data over the period 1978-2000. Arellano and Bond's dynamic panel data estimating technique and Pedroni's panel unit root test were used for analysis. Result suggested both FDI and exports exerted positive effect on the economic development.

Khaliq et al. (2007) thesis explores the impact of FDI on economic development on aggregate level using comprehensive sectoral data for FDI inflows to Indonesia over the period 1997-2006 using Cobb-Dogllus production function. Results suggested that some sector shows positive impact on FDI, but mining \& quarrying shows negative impact on FDI inflows. Iram and Nishat (2009) the effect of services and manufacturing FDI on economic development in the presence of macroeconomic Instability and privatization over the period of 1972 to 2008 by using Philips-Perron unit root and Augmented Dickey Fuller. Results conclude that in the short run, both manufacturing FDI and services FDI do not significantly affect economic development. However, in the long run manufacturing FDI and services FDI significantly affect economic development.

Hermes and Lensink (2003) examined the function of the expansion of the financial system plays in ornamental the optimistic affiliation among FDI and economic development. Data which used was taken from 67 countries in data set by using correlation matrix. The result showed that 37 out of 67 countries have an adequately developed financial system and in these FDI added optimistically to economic development. Tian, Io Lo, Lin, and Song (2011) scrutinized the spatial dimension of FDI output spillovers in transition economies. The data which is adopted for this research was from China. The study found that FDI in the growth pole on the coast adversely affects the efficiency of domestic firms in the peripheral interior.

$\mathrm{Xu}$ (2012) examined whether comparatively stumpy benefits of FDI on economic development in China was due to poor financial market development by using Evidence Blundell-Bond system to estimate. A dynamic panel data model from provincial data 1999-2006. Study reveals In contrast, FDI creates positive impact on economic development if credits are associated to small private enterprises, while FDI creates negative impact one economic development if credits are associated to banks unproductive state-owned enterprises (SOEs). Inekwe (2013) scrutinizes the bonds among FDI and Nigerian economic development, employment and in the manufacturing and servicing division's period from 1990 and 2009. The tests which are used in the research are vector error correction and Johansen co integration technique. Results revealed that FDI in the manufacturing sector has a pessimistic affiliation while FDI in the servicing division has a optimistic link with economic development. FDI in the servicing sector has a negative bond with employment pace while in the manufacturing sector it has a positive connection with employment rate. 
Adeleke (2014) observes the effects of governance on FDI-growth nexus in Africa using both levels aggregate and disaggregates by using panel data technique to scrutinize the interrelationship and the variables which used are gross domestic product (GDP), FDI, and governance (GOV). Results suggested that FDI attract GDP but must augment their governance structure. The above past studies indicate that FDI has negative, insignificant, or some sectors possesses negative effect of FDI on economic development. If we review the past studies, it can be concluded that the FDI affects economic growth in different ways, FDI may act as boon or bane for the host country so there was a need for the expansion of study with new data set and our research will aims to cover the existing gap.

\section{Modeling Framework of the Study}

Our empirical estimates started with the augmented Cobb-Douglas production function framework (1). The model is to estimate the effect of FDI namely manufacturing, construction, and mining \& quarrying on industrial growth in parametric form we can define it as follows:

$$
Y_{i t}=\alpha_{i t}+\beta_{1} 1 L A B_{i t}+\beta_{2} C A P_{i t}+\beta_{3} F D I_{i t}+\epsilon_{i t}
$$

Where $\mathrm{Y}=$ is the industrial output gross domestic product (GDP), LAB is for labor force, CAP represents gross capital formation as a percentage of GDP (CAP), FDI represents FDI, e denotes error and 'it' represents that it was a disaggregate equation. The data used in this research cover three sectors manufacturing, construction and mining \& quarrying $(n=3)$ and the model is estimated by using 14 years $(t=14)$ of annual data from the period 1997-2011. We have used disaggregate FDI, CAP, LABOR and GDP in our research to measure the actual effects of these variables on its particular sectors. The research adopted three sectors of Pakistan first manufacturing second construction and the third one was mining \& quarrying. The data was obtained from the Federal bureau of statistics and Hand book of statistics of State bank Pakistan (SBP) and ministry of finance Pakistan ${ }^{2}$.

Now the techniques which were used to check that whether the data is stationary or not, we have adopted three methods such as PP Statistics panel unit root (Choi, 2001), ADF Statistic (Maddala \& Wu, 1999), IPS in panel unit root test (Im, Pesaran, \& Shin, 2003), to discover the long-relationship among the variables Chaiboonsri, Sriboonjit, Sriwichailamphan, Chaitip, and Sriboonchitta (2010) used all five methods. Our research adopted three methods in cointegration Johansen Fisher, Kao residual cointegration and Pedroni residual cointegration tests to find long relationship among dependent and independent variables and to find the coefficient we have used OLS.

\section{Estimation and Results}

The actual intent of this research is to scrutinize the impact of construction manufacturing and mining quarrying FDI on industrial growth of Pakistan. We have chosen up three sectors which include manufacturing, construction, mining \& quarrying.

\footnotetext{
${ }^{2}$ http://www.finance.gov.pk/
} 
Moreover we adopted least square technique in regression analysis to find the impact of sectoral FDI on industrial growth of Pakistan. The impact of independent variable on dependent variable will be classified by the following analysis.

\section{Summary Statistics}

For the interpretation of basic properties of data we used the above statistic. The maximum shows the upper limit value and the minimum shows the lower limit value of the variables.

Table 1: Descriptive Statistic

\begin{tabular}{llcccc}
\hline & & FDI & CAP & LAB & GDP \\
\hline \multirow{5}{*}{ Overall } & MEAN & 2.444 & 1.456 & 2.960 & 6.927 \\
& MAX & 13.759 & 4.286 & 7.359 & 19.042 \\
& MIN & 0.247 & 0.092 & 0.092 & 0.472 \\
& STD.DEV & 3.164 & 1.402 & 1.402 & 6.625 \\
\hline \multirow{5}{*}{ Manufacturing Sector } & MEAN & 5.386 & 3.291 & 5.918 & 16.043 \\
& MAX & 13.759 & 4.286 & 7.359 & 19.042 \\
& MIN & 1.181 & 1.437 & 3.679 & 13.664 \\
\hline \multirow{5}{*}{ Construction Sector } & MEAN & 1.043 & 0.341 & 2.915 & 2.456 \\
& MAX & 4.080 & 0.661 & 3.800 & 3.350 \\
& MIN & 0.516 & 0.092 & 2.157 & 2.048 \\
\hline \multirow{5}{*}{ Mining \& Quarrying Sector } & MAX & & & & \\
& MIN & 0.247 & 0.237 & 0.0261 & 0.472 \\
\hline Source: Authors' Estimation & & & & &
\end{tabular}

\section{Panel Unit Root Test}

Research shown that unit root test based on individual time series have less power than panel-based unit root tests (Breitung, 2000; Levin, Lin, \& Chu, 2002; Im et al., 2003). We use Im, Pesaran and Shin unit root test and Fisher-Type unit root test using Augmented Dickey Fuller and Philips-Perron test statistics to analyze the stationary properties of considered variables (Maddala \& Wu, 1999; Choi, 2001; Im et al., 2003).

Table 2: Results of Panel Unit Root Test of All Variables at Level

\begin{tabular}{|c|c|c|c|c|c|c|c|c|c|}
\hline \multirow{3}{*}{ Variables } & \multicolumn{3}{|c|}{ Im, Pesaran, Shin } & \multicolumn{3}{|c|}{ ADF test statistics } & \multicolumn{3}{|c|}{ PP test statistics } \\
\hline & \multicolumn{3}{|c|}{$1(0)$} & \multicolumn{3}{|c|}{$1(0)$} & \multicolumn{3}{|c|}{$1(0)$} \\
\hline & $\mathrm{C}$ & C\&T & RESULTS & $\mathrm{C}$ & $\mathrm{C} \& \mathrm{~T}$ & RESULTS & $\mathrm{C}$ & $\mathrm{C} \& \mathrm{~T}$ & RESULTS \\
\hline FDI & 2.563 & 1.768 & Non stationary & 3.930 & 4.333 & Non stationary & 4.226 & 4.333 & Non stationary \\
\hline CAP & -0.308 & 1.410 & Non stationary & 6.526 & 2.984 & Non stationary & 6.226 & 2.858 & Non stationary \\
\hline $\mathrm{LAB}$ & -0.087 & -0.372 & Non stationary & 5.759 & 7.519 & Non stationary & 9.068 & 18.276 & Non stationary \\
\hline GDP & -0.381 & -0.308 & Non stationary & 6.251 & 4.752 & Non stationary & 6.650 & 2.272 & Non stationary \\
\hline
\end{tabular}


In table $2 \& 3$, we present the results of unit root tests of all the variables considered in this research. The results show that all variables are non-stationary at level but, after taking the first difference, they all becomes stationary (see table 3). Therefore, it is concluded that there is no several issue of unit root exists in our variables and we can use the same variables for further estimations.

Table 3: Results of Panel Unit Root Test of All Variables at First Difference

\begin{tabular}{|c|c|c|c|c|c|c|c|c|c|}
\hline \multirow{3}{*}{ Variables } & \multicolumn{3}{|c|}{ Im, Pesaran, Shin } & \multicolumn{3}{|c|}{ ADF test statistics } & \multicolumn{3}{|c|}{ PP test statistics } \\
\hline & \multicolumn{3}{|c|}{$1(1)$} & \multicolumn{3}{|c|}{$1(1)$} & \multicolumn{3}{|c|}{$1(1)$} \\
\hline & $\mathrm{C}$ & $\mathrm{C} \& \mathrm{~T}$ & RESULTS & $\mathrm{C}$ & $\mathrm{C} \& \mathrm{~T}$ & RESULTS & $\mathrm{C}$ & C\&T & RESULTS \\
\hline FDI & -3.835 & -3.383 & Stationary & 20.117 & 21.458 & Stationary & 23.332 & 22.115 & Stationary \\
\hline CAP & -2.194 & -2.104 & Stationary & 15.042 & 13.875 & Stationary & 15.556 & 13.780 & Stationary \\
\hline LAB & -4.172 & -0.372 & Stationary & 56.109 & 54.664 & Stationary & 56.664 & 49.427 & Stationary \\
\hline GDP & -2.560 & -2.368 & Stationary & 16.879 & 16.159 & Stationary & 15.44 & 16.264 & Stationary \\
\hline
\end{tabular}

\section{Panel Co-Integration Test}

In this study, we used three econometric techniques of panel co-integration namely; Pedroni panel co-integration, Kao Residual based co-integration and Fisher Johansen based co-integration to analyze the long run relationship between variables. The null hypothesis of all co-integration methods is that there is no long run co-integration exist between variables. Table 4 represents the results of co-integration analysis. The results of all applied co-integration methods confirm the existence of significant long run relationship between variables. 
Table 4: Pedroni Residual Co-Integration Tests

\begin{tabular}{lcc}
\hline \multicolumn{1}{c}{ Test Name } & Statistic & $\begin{array}{c}\text { Sig. level } \\
\text { for rejection } \\
\text { (no co integration })\end{array}$ \\
\hline (1) Pedroni Residual Co-Integration Tests & \\
\hline Panel v-Statistic & -0.136 & 0.554 \\
Panel rho-Statistic & -0.144 & 0.442 \\
Panel Philips-PerronStatistic & -3.076 & 0.001 \\
Panel Augmented Dickey Fuller-Statistic & -3.755 & 0.000 \\
Group rho-Statistic & 0.795 & 0.786 \\
Group Philips-Perron-Statistic & -2.977 & 0.001 \\
Group Augmented Dickey Fuller-Statistic & -5.220 & 0.000 \\
& & \\
\hline (2) Kao Residual Co-Integration Tests & & \\
\hline Augmented Dickey Fuller-Statistic & & \\
& & \\
\hline (3) Johansen Fisher Panel Co-Integration Test & & \\
\hline Fisher Statistics from Trace Test & & \\
At Most 1 & & \\
At Most 2 & & \\
At Most 3 & & \\
Fisher Statistics from Max-Eigen Test & 57.58 & 0.042 \\
At Most 1 & 25.16 & 0.000 \\
At Most 2 & 14.97 & 0.020 \\
At most 3 & 41.68 & 0.000 \\
Source: Authors' Estimation & 21.03 & 0.001 \\
& 14.97 & 0.020 \\
\hline
\end{tabular}

\section{Ordinary Least Square}

Table 5: Ordinary Least Square Test

\begin{tabular}{lccc}
\hline \multicolumn{1}{c}{ Variables } & Coefficient & T-Statistics & Prob \\
\hline C & 0.468 & 1.194 & 0.239 \\
LAB & 0.756 & 4.626 & 0.000 \\
CAP & 2.946 & 11.378 & 0.000 \\
FDI & 0.353 & 3.256 & 0.002 \\
\hline Adjusted-R ${ }^{2}$ & & 0.9366 & \\
F-Statistics & & 217.99 & \\
Prob (F-Statistics) & & 0.000 & \\
\hline Source: Authors' Estimation & & &
\end{tabular}

The results of long run analysis are presented in table5. Results confirm the positive and significant impact of sectoral foreign direct investment on industrial economic growth of Pakistan. The motive behind the significant and the positive relationship between FDI and the economic expansion of Pakistan, when there is an inflow of FDI in the host country like Pakistan its shows the stability of economy its effects positively on production which help to increase the gross domestic product (GDP) there are many other positive spillover of FDI, inflow of FDI introduces new companies \& firm, 
increases employment, and FDI inflow. FDI represents the transfer of a package which include new technology and funds management (Hymer, 1976). Moreover ameliorate the level of skilled labor workers in the host country.

Results also suggest the positive and significant influence of labour force and capital on industrial development in Pakistan. The core motive of positivity and significant association between economic development and labor is if employment amplifies purchasing power of people increases due to which it helps to attract more production. The rate of attracting more production will be higher if the country have young and skilled labors and they will be beneficial and will be more favorable for economic growth of the country because it has found in some research the rate of increase is depend on the gender and skilled labors age. The above data shows capital has positive and considerable association with economic augmentation and the reasons behind it is when capital increase its directly effect on the gross domestic product (GDP) of the host country as well as it is very imperative to consider all determination of gross fixed capital formation (CAP) to find out the gross domestic product (GDP) of a nation.

\section{Granger Causality Test}

To investigate the causal relationship between FDI and industrial economic expansion we have adopted Granger causality. To discover out the causation and the direction between two variables standard granger causality (Granger, 1969) has been utilized. Jones (1989) express that if we compare selection method of optimal lag length, the ad hoc selection in granger causality is better than any statistical methods for determining optimal lag. Consequently, for granger causality analysis we found Uni-directional results at lags 1, 2, 3 but if we go for lags 4 for the models of Gross domestic product (GDP) and FDI we got bi-directional results among the variables. The Table 6 explained the result of Granger causality.

Table 6: Granger Causality Test Results

\begin{tabular}{lcccc}
\hline NULL HYPOTHESIS & Lags & F-Statistic & Prob & Results \\
\hline FDI does not Granger Cause GDP & \multirow{2}{*}{1} & 0.330 & 0.568 & Uni-directional \\
GDP does not Granger Cause FDI & & 5.503 & 0.024 & GDP $->$ FDI \\
FDI does not Granger Cause GDP & \multirow{2}{*}{2} & 0.318 & 0.729 & Uni-directional \\
GDP does not Granger Cause FDI & & 7.276 & 0.002 & GDP $->$ FDI \\
FDI does not Granger Cause GDP & \multirow{2}{*}{3} & 0.375 & 0.771 & Uni-directional \\
GDP does not Granger Cause FDI & & 6.307 & 0.002 & GDP $->$ FDI \\
FDI does not Granger Cause GDP & \multirow{2}{*}{4} & 3.048 & 0.036 & Bi-directional \\
GDP does not Granger Cause FDI & & 5.297 & 0.003 & \\
\hline Source: Authors' Estimation & & & &
\end{tabular}

Results of Table 6 illustrate that there is bi-directional causality exist between the economic developments (GDP) and the FDI. It means that after almost four years FDI will starts to shows its effect on industrial growth. 


\section{Conclusions and Policy Recommendation}

This research empirically investigated the impact of sectoral FDI namely manufacturing, construction, mining \& quarrying on industrial growth of Pakistan over period of 1997 to 2011. In order to find out the order of mixing, we used IM Pesaran, Augmented Dickey Fuller and Philips-Perron unit root tests.

We used Pedroni Residual co-integration test, (Kao, 1999) Augmented Dickey Fuller test, and combined individual test (Fisher/Johansen) to test out the long-run relationship among dependent variable (GDP) and the group of self-governing variables, we found that in the long run sectoral FDI, capital (CAP) and labor (LAB) significantly affect industrial economic upswing. The outcome also shows that FDI contribute optimistically and considerably to industrial economic development. However, after the results the policy recommendation is to magnetize the variables which help in attracting FDI in Pakistan.

Government must pay proper attention in variables which reflects liberalization of financial \& fiscal sectors and trade, variables such as, exchange rate, credit to private sector, excise rate, tax rate, and indicator of general share price these policy variables are significantly effective for attraction of FDI for both in short term as well as long term in the country. Government of Pakistan should do some reduction in corporate tax and import excise would affirmatively affect the rate of FDI inflow similarly when exchange rate coefficient is affirmative resulting the appreciation of rupee in the international market exerts strong economy signs and it will also build up confidence in the foreign investors to invest in the country. Moreover generous credit policy will also help plenty to development of FDI.

FDI should be encouraged to strengthen economic growth, to lift up living standards to restrain poverty and unemployment to amplify benefit of innovative technology, but we must not forget to give proper attention should also be paid to maintain profit outflow and to prevent people from the monopolies of the multinational firms and to save sovereignty of the country. In order to enhance growth, policies should device to attract export oriented FDI instead of domestic demand oriented. 


\section{References}

Addison, T., \& Heshmati, A. (2003). The new global determinants of FDI flows to developing countries: The importance of ICT and democratization (No. 2003/45). WIDER Discussion Papers//World Institute for Development Economics (UNU-WIDER).

Adeleke, A. I. (2014). Fdi-Growth Nexus In Africa: Does Governance Matter? Journal of Economic Development, 39(1), 111-135.

Aitken, B. J., \& Harrison, A. E. (1999). Do domestic firms benefit from direct foreign investment? Evidence from Venezuela. American economic review, 605-618.

Alfaro, L. (2003). Foreign direct investment and growth: Does the sector matter. Harvard Business School, 1-31.

Atique, Z., Ahmad, M. H., \& Azhar, U. (2004). The Impact of FDI on Economic Growth under Foreign Trade Regimes: A Case Study of Pakistan. The Pakistan Development Review, 43(4), 707-718.

Bengoa, M., \& Sanchez-Robles, B. (2003). Foreign direct investment, economic freedom and growth: new evidence from Latin America. European journal of political economy, 19(3), 529-545.

Blomström, M., \& Kokko, A. (1996). The impact of foreign investment on host countries: a review of the empirical evidence. Policy Research Working Paper, 1745.

Blomstrom, M., Lipsey, R. E., \& Zejan, M. (1992). What explains developing country growth? (Tech. Rep.). National bureau of economic research.

Borensztein, E., De Gregorio, J., \& Lee, J.-W. (1998). How does foreign direct investment affect economic growth? Journal of international Economics, 45(1), 115-135.

Boss, E., Taylor, L., Gilbert, S., Gundersen, K., Hawley, N., Janzen, C., ... others (2009). Comparison of inherent optical properties as a surrogate for particulate matter concentration in coastal waters. Limnology and Oceanography: Methods, 7(11), 803-810.

Breitung, J. (2000). The local power of some unit root tests for panel data. in: Baltagi, b. h., ed. Nonstationary Panels, Panel Cointegration, and Dynamic Panels, 161-177.

Caves, R. E. (1971). International corporations: The industrial economics of foreign investment. Economica, 1-27.

Caves, R. E. (1974). Multinational firms, competition, and productivity in host-country markets. Economica, 176-193.

Chaiboonsri, C., Sriboonjit, J., Sriwichailamphan, T., Chaitip, P., \& Sriboonchitta, S. (2010). A panel cointegration analysis: an application to international tourism demand of Thailand. OF THE UNIVERSITY OF PETROSANI ECONOMICS, 69.

Choi, I. (2001). Unit root tests for panel data. Journal of international money and Finance, 20(2), 249-272.

Chowdhury, A., \& Mavrotas, G. (2005). FDI and growth: a causal relationship (No. 2005/25). Research Paper, UNU-WIDER, United Nations University 
(UNU).

Dunning, J. H. (1993). Multinational enterprises and the global economy. Addisson-Wesley Publishing Company, Reading.

Economic, \& Survey. (2012-2013). Economic survey of Pakistan. Finance Division, Advisor's Wing, Government of Pakistan.

Felipe, J. (1999). Total factor productivity growth in East Asia: A critical survey. The Journal of Development Studies, 35(4), 1-41.

Firebaugh, G. (1992). Growth effects of foreign and domestic investment. American Journal of Sociology, 105-130.

Foreign direct investment flows. (2015). Retrieved from http://www.sbp.org .pk/departments/stats/pakEconomy_HandBook/Chap-7.12.pdf

Granger, C. W. (1969). Investigating causal relations by econometric models and cross-spectral methods. Econometrica: Journal of the Econometric Society, 37(3), 424-438.

Hein, S. (1992). Trade strategy and the dependency hypothesis: A comparison of policy, foreign investment, and economic growth in Latin America and East Asia. Economic Development and Cultural Change, 495-521.

Hermes, N., \& Lensink, R. (2003). Foreign direct investment, financial development and economic growth. The Journal of Development Studies, 40(1), 142-163.

Highlights pakistan economic survey 2012-13. (2015, January). Retrieved from http://www.finance.gov.pk/survey/chapters_13/ HGHLIGHTS\%202013.pdf

Hymer, S. H. (1976). The international operations of national firms: A study of direct foreign investment (Vol. 14). MIT press Cambridge, MA.

Im, K. S., Pesaran, M. H., \& Shin, Y. (2003). Testing for unit roots in heterogeneous panels. Journal of econometrics, 115(1), 53-74.

Inekwe, J. N. (2013). FDI, employment and economic growth in Nigeria. African Development Review, 25(4), 421-433.

Iram, S., \& Nishat, M. (2009). Sector level analysis of FDI-growth nexus: a case study of Pakistan. The Pakistan Development Review, 875-882.

Jones, J. D. (1989). A comparison of lag-length selection techniques in tests of Granger causality between money growth and inflation: evidence for the US, 1959-86. Applied Economics, 21 (6), 809-822.

Kao, C. (1999). Spurious regression and residual-based tests for cointegration in panel data. Journal of Econometrics, 90, 1-44.

Katerina, L., John, P., \& Athanasios, V. (2004). Foreign direct investment and economic growth in transition economies. South-Eastern Europe Journal of Economics, 1, 97-110.

Khaliq, A., Noy, I., et al. (2007). Foreign direct investment and economic growth: Empirical evidence from sectoral data in Indonesia. visit http://www. economics. hawaii. edu/research/workingpapers/WP_07-26. $p d f$.

Kindleberger, C. P. (1984). Multinational excursions. MIT Press Books, 1.

Kobrin, S. J. (2005). The determinants of liberalization of fdi policy in de- 
veloping countries: a cross-sectional analysis, 1992-2001. Transnational Corporations, 14(1), 67-104.

Koizumi, T., \& Kopecky, K. J. (1977). Economic growth, capital movements and the international transfer of technical knowledge. Journal of International Economics, 7(1), 45-65.

Levin, A., Lin, C.-F., \& Chu, C.-S. J. (2002). Unit root tests in panel data: asymptotic and finite-sample properties. Journal of econometrics, 108(1), $1-24$.

Maddala, G. S., \& Wu, S. (1999). A comparative study of unit root tests with panel data and a new simple test. Oxford Bulletin of Economics and statistics, 61(S1), 631-652.

Singer, H. W. (1950). The distribution of gains between investing and borrowing countries. The American Economic Review, 473-485.

Tian, X., Io Lo, V., Lin, S., \& Song, S. (2011). Cross-region FDI productivity spillovers in transition economies: evidence from China. Post-communist economies, 23(01), 105-118.

Uttama, N. P. (2011). Spatial panel cointegration analysis on FDI-IIT-growth nexus in ASEAN. International Proceedings of Economics Development \& Research, 10.

World investment report. (1999).

$\mathrm{Xu}, \mathrm{Y}$. (2012). How does financial system efficiency affect the growth impact of FDI in China? Evidence from provincial data 1999-2006. China Finance Review International, 2(4), 406-428.

Yao, S. (2006). On economic growth, FDI and exports in China. Applied Economics, 38(3), 339-351. 